This is an open access article under the CC BY-NC-ND license (https://creativecommons.org/licenses/by-nc-nd/3.0/) Issue II, November 2019

ISBN 978-601-323-144-0

https://doi.org/10.31643/2019.002

\author{
Samal Suleimen \\ Abai KazNPU, Kazakhstan \\ E-mail: samalka__94@mail.ru \\ ORCID ID 0000-0001-8523-0478
}

\author{
Aidana Orazayeva \\ Abai KazNPU, Kazakhstan \\ E-mail: a_nurbolatovna@mail.ru ORCID \\ ID 0000-0001-5801-2459
}

\title{
Informational cultural description of the future teacher- manager in the education system
}

\begin{abstract}
This article is a review paper about a teacher manager. Authors try to explain that teachers should manage information well and they should also use it efficiently during their work process. The abilities of the use and use of information are the key to increasing the relevance of the need for continuous education in the transition to an information society. Authors did a great job in the literature review in Kazakhstani references on the education management system. A teacher as a manger in the classroom should solve all the issues appeared during the lessons without any problem. They should have problem solving skills. The authors also outline the importance that the teacher should possess informational culture shows the three steps of an informational culture of teacher-manager. This paper also specifies five characteristics of the informational culture of the future teacher.

Keywords: teacher-manager, information, education, society, challenges, ability to solve problems, management, information culture, personality and professional activities.
\end{abstract}

Introduction. Nowadays a teacher is considered to be a manager in the education system. Their responsibilities include not only knowledge transition and education, but they should also be well-prepared managers in order to run their teaching process smoothly and to deal with challenges. Challenges might be with different kind of personalities or financial issues etc. A key role of teachers is to tackle all the problems in the education system and to create a good study atmosphere for students. Thus, the teacher role is gradually changing from simplicity into complexity and is being integrated with another profession. Future teachers should be competent in their work since they are educating the youth of the country. Educational venue is a place oriented to formation of trainees in obtaining knowledge and abilities specific to their job. Nowadays, it is important for every person who accumulates knowledge to be competent in the labor market after graduating from university (Kassymova, G. 2018). All occupations involve performance of some relatively specific tasks; however, it is not enough to be an expert in the field what a student have studied at university, i.e. in the theory. They should also be able to aware of what is happening out of their workplaces in order to be a competent teacher in the labour world.

In the process of globalization, educational globalization is particularly noticeable. Globalization as a cultural phenomenon involves the spread of modern economic, legal, sociological other theories, including by means of digital technologies - in the field of their application to the transformation of science, art and education. Globalization aims at the transmission of values, models of understanding yourself and the world, communication models of countries moves from the upbringing and training of the person (Arpentieva, M., 2018).

There is no doubt, in addition to their professional knowledge and skills in the 21st century, the person who uses the new opportunities of information society is considered to be a professional. Creating an informational culture of professionals is the most effective way to use these opportunities. At present, each expert, first of all, should be able to work with large amounts of information, to be adequately perceived and used efficiently.

At the same time, people with the constant growth of information and the possibilities for it, its processing, acquisition, use in professional activities are capable of accurately and quickly evaluating and publicly accessible information than other people, constantly growing information and receiving, processing, 
assimilation. The possibilities of the use and use of information are the key to increasing the relevance of the need for continuous education in the transition to an information society, building a motivational basis, and forming a high level of knowledge, skills and abilities.

Research results. As we all know, radical changes in the culture of information society take on the status of strategic resource. During the implementation of various activities, especially in the management process, the use of the above resource, tactical and operational aspects of the formation of personality information culture are considered.

Based on our analysis of scientific and pedagogical references, we have determined that $\mathrm{Yu}$. Hayashi, professor of the Tokyo Institute of Technology has introduced the term "information society" for the first time.

The scientist, who research the same study as this paper title, Zboryovsky said: "Information society - the creation and distribution of goods and services, their creation, processing and distribution of information will depend on the manufacturer" [1].

In the reports of a number of organizations submitted to the Japanese government the main characteristics of the education community includes the following organizations:

$>$ the Economic Development Agency;

$>$ the Computer Development Institute;

$>$ the Industrial Structure Board.

The following are also mentioned in the titles:

$>$ "Japanese Society of Information: Themes and Approaches" (1969);

$>$ "Japanese Incentive Policy in Informatization" (1969);

$>$ "Information Society Plan" (1971).

High industrial society has been identified through the development of computerization by providing people with access to reliable sources of information and providing them with a high level of automation at work, giving them daily work. At the same time, substantial changes directly affect the production, as a result increases the productivity of the product, which greatly increases the value of its innovation, design and marketing.

The peculiarity of today's society is that production of information products, not material goods, is a driving force of education and social development.

Before discussing the expert culture, it is primarily the group's recognized professional services (professional roles). Professional activities include the performance of certain professional functions. This combination is usually associated with a tradition of professional culture, which ensures the continuity and integrity of professional activities.

A special discipline "Management in education" has been introduced in curricula of pedagogical specialties of bachelor in higher education in Kazakhstan. It is worth mentioning that the work, which has practical significance for the concept of management in Kazakhstan, is a methodical guide of K. D. Karakulov, "Improving School Principal Managerial Activities" published in 1990, in which the issues of improving governance in general education schools in the conditions of democratization are discussed (Karakulov, K. D., 1990).

Another important activity in the education management system is that Abai Kazakh National Pedagogical University conducted out one experimental faculty in master's degree and all the participants successfully graduated from the Institute of Pedagogy and Psychology at Abai University in the curriculum year 20182019.

Table - Research on Kazakhstani educational management issues between 2001-2017

\begin{tabular}{|l|l|c|}
\hline First and last name & \multicolumn{1}{|c|}{ Research title } & Defense date \\
\hline Abishov N. A. & $\begin{array}{l}\text { Scientific basis of cooperation between pedagogical collectives of } \\
\text { innovation schools and educational management bodies in reforming } \\
\text { the modern school of Kazakhstan }\end{array}$ & 2001 \\
\hline
\end{tabular}


Materials of International Practical Internet Conference "Challenges of Science”

\begin{tabular}{|c|c|c|}
\hline Adilgazinov G. Z. & $\begin{array}{l}\text { Theoretical bases of improvement of teachers' pedagogical process } \\
\text { control in small-scale school }\end{array}$ & 2002 \\
\hline Rysbekova A. K. & $\begin{array}{l}\text { Pedagogical bases of management of scientifically-methodical } \\
\text { works in a gymnasium }\end{array}$ & 2002 \\
\hline Tuxanbaev A. & $\begin{array}{l}\text { Pedagogical conditions of formation of managerial culture of the } \\
\text { school principal in the system of professional development of } \\
\text { managerial staff }\end{array}$ & 2004 \\
\hline Batalov Yu.V. & $\begin{array}{l}\text { Economic and management problems and ways to improve the } \\
\text { training of specialists with higher education }\end{array}$ & 2005 \\
\hline Kozybayev E. Sh. & $\begin{array}{l}\text { Scientific and pedagogical bases of management of modern high } \\
\text { school on the basis of management in multi-level education }\end{array}$ & 2006 \\
\hline Kim L. N. & $\begin{array}{l}\text { Pedagogical conditions of management of educational process in } \\
\text { non-state Higher Education Institutions }\end{array}$ & 2006 \\
\hline Kulibaeva D. N. & $\begin{array}{l}\text { Methodological bases of management of professional-oriented } \\
\text { educational system of international type schools }\end{array}$ & 2007 \\
\hline Kalieva S. N. & $\begin{array}{l}\text { Improving the management of the Kazakh school in the modern } \\
\text { socio-cultural context }\end{array}$ & 2008 \\
\hline Kuspanov A. B. & Higher school management as a function of a social institution & 2008 \\
\hline Baimoldaev T. M. & $\begin{array}{l}\text { Scientific and pedagogical bases of general education school } \\
\text { management }\end{array}$ & 2009 \\
\hline Islamgulova S. K. & $\begin{array}{l}\text { The theory and practice of management of development of } \\
\text { pedagogical system of general secondary education }\end{array}$ & 2009 \\
\hline Bayzhikenova G. K. & $\begin{array}{l}\text { Development of innovative management of the whole pedagogical } \\
\text { process of the modern school }\end{array}$ & 2010 \\
\hline Umirbekova Zh. B. & $\begin{array}{l}\text { Pedagogical and organizational bases of management of education } \\
\text { in conditions of globalization of modern society }\end{array}$ & 2010 \\
\hline Sailybaev B. & $\begin{array}{l}\text { Scientific bases of continuity in teacher training in the system of } \\
\text { continuing professional and pedagogical education }\end{array}$ & 2010 \\
\hline Zhunusbekova A. & Prepare future elementary school teachers for managerial activities & 2015 \\
\hline Knysarina M. & Formation of managerial skills of younger school age students & 2016 \\
\hline Adanov K. B. & $\begin{array}{l}\text { Formation of management culture in the process of vocational } \\
\text { training of future elementary school teachers }\end{array}$ & 2017 \\
\hline Aganina K. Zh. & Management in the Education system & 2017 \\
\hline
\end{tabular}

In Kazakhstan, there have been done many research works on the education revolution (Table). The analysis of the content of these researches allowed to consolidate the issues of management in the field of education in domestic scientific literature:

$>$ The theory and practice of pedagogical process of general education school

Scientific and pedagogical bases of management of the university, pedagogical conditions,

$>$ features 
$>$ Theoretical-methodological bases of the preparation of training of heads of educational organizations

$>$ Scientific basis of interaction, continuity in the management of educational organizations

$>$ Theoretical bases of development of managerial activity of the future teacher, formation of management culture, experimental experience, etc. These works show that the problem of future teacher-managers' management work is not studied well yet.

Our study is related to the last group about future teacher-managers. As can be seen from the table, there are many researchers who are dedicating their work to educational management in the last two decades.

Research discussion. Over the past decade, the Internet has become an integral part of life for the majority of the population. Of course, the Internet is of great importance in the modern world and brings great benefits to humanity: as an inexhaustible source of information, a tool for organizing the educational process, as an indispensable assistant in work and business, as a means of conducting and planning leisure time and much more (Lavrinenko, S. V., Arpentieva, M. R., \& Kassymova, G. K., 2019). As specific literature analysis shows, information culture is characterized by operational skills related to information. In turn, it entails an informational outlook that is closely linked to information needs and values, information thinking, communication with the environment and people, and specific information activities.

Today, the analysis of the requirements for the professional competence of the manager allows to define the steps of the information culture (Figure 1).

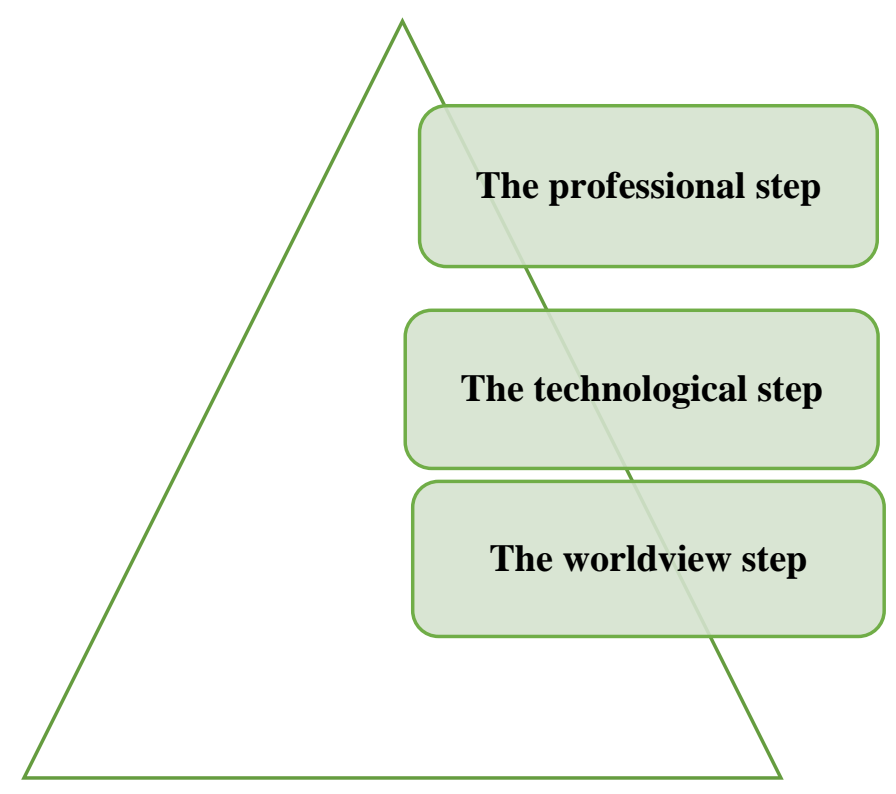

Figure-1 Steps of an informational culture of teacher-manager

The next point of the study is to talk about the steps of information culture of teacher-manager:

$>$ The worldview step of an informational culture of teacher-manager means an involvement of the manager on the impact of information processes and technologies on the development of modern society, the structure and content of employees at all levels and the social impact of informing the public;

$>$ Knowledge of methods and methods of information work on the basis of the technological step of an informational culture of teacher-manager, traditional and new information-computer methods, their use as a tool in education and management;

The use of information in the professional step of an informational culture of teacher-manager and professional activities and, first of all, provides an effective system of information resources, the formation of an information base for managing decisions, and accumulation of experience in 
determining the relevance of information resources within the organization's operational and strategic management.

As noted above, information culture is presented as an integral qualitative characteristic of a person in the postindustrial society. This will help to develop a professional culture of the specialist, which in turn will allow to regularly evaluate the knowledge and information contained in the info center, to link them to the most important knowledge and information models for the acquisition and application of new knowledge. Therefore, the importance of information culture is important now (Figure 2).

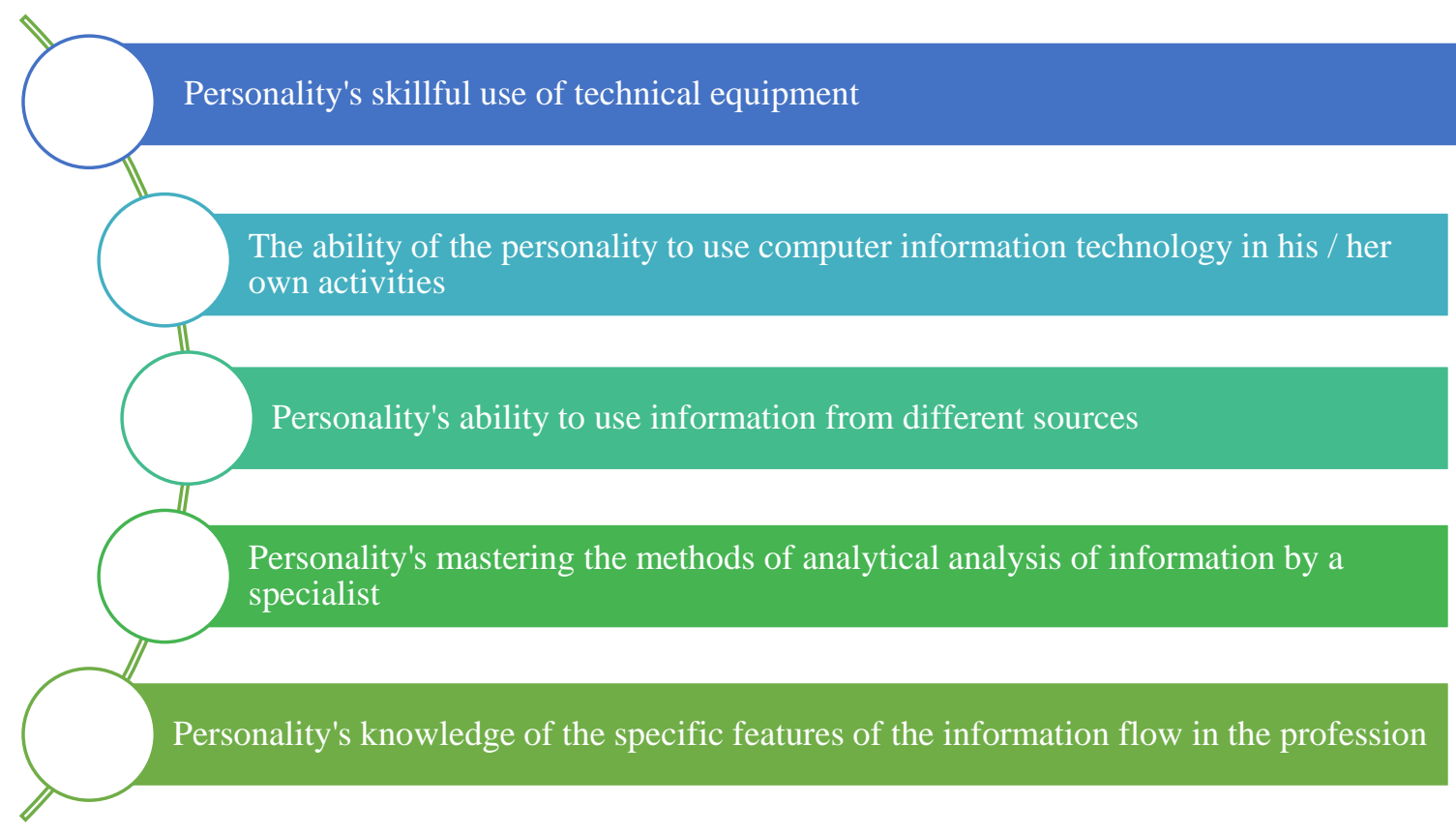

Figure-2 Characteristics of the informational culture of the future teacher

Another point of this study is to specify the characteristics of the informational culture of the future teacher:

- Personality's skillful use of technical equipment means individual skills in using technical equipment (from personal computer to computer networks);

- The ability of the personality to use computer information technology in his / her own activities means the ability to use computer information technology in its activities, the main component of which is the many software products;

- Personality's ability to use information from different sources means the ability to evaluate and effectively use the individual's various sources, including electronic communications;

- Personality's mastering the methods of analytical analysis of information by a specialist implies knowledge of the specialist through analytical information processing;

- Personality's knowledge of the specific features of the information flow in the profession states knowledge of the specifics information flows in the field of professional activities [2].

Conclusion. As a result, the information culture has a complex structure as part of the overall and professional culture of the future manager, which includes two blocks: information outlook and information activities. There are also three steps of an informational culture of teacher-managers and five characteristics of the informational culture of the future teachers. As a scientist, M. Arpentieva (2018) states that mankind has repeatedly faced serious changes, information flows and the need for change management, especially in education. The current stage is no different: it's like in previous centuries, mankind seeks the truth, even if it seems to him that it is impossible to find and transmit it. The university as a place of dialogue between generations, a place of dialogue between man and culture, will live. Its forms and priorities will change, but its main functions will not disappear: people will always have something to share with others, what to convey to others, what to discover - in themselves and in the world. 
Acknowledgement. Authors would like to express their gratitude to the Ministry of Education and Science of the Republic of Kazakhstan for allocating them the scholarship to study this research at Abai Kazakh National Pedagogical University in the period of the curriculum year between 2018 and 2020.

Cite this article as: Suleimen, S., Orazayeva, A., (2019) Informational cultural description of the future teacher-manager in the education system. Materials of International Practical Internet Conference "Challenges of Science". ISBN 978-601-323-144-0. Issue II, 2019. Page 14 - 19. https://doi.org/10.31643/2019.002

\section{References}

[1] Arpentieva, M. Destruction of the University: from a "Comprehensively Developed Personality" to a "Robustly Robust Specialist” (Арпентьева, М. Разрушение университета: от «Всесторонне развитой личности» к «робото утойчивому специалисту»). Challenges of Science (In Russian), 2018. https://doi.org/10.31643/2018.002

[2] Karakulov, K. D. Improving the management of the school director (Каракулов К.Д. Совершенствование управленческой деятельности директора школы) . - Almaty, 1990. - P. 28.

[3] Kassymova, G. Competence and its implications. Challenges of Science., 2018. https://doi.org/10.31643/2018.063

[4] Lavrinenko, S. V., Arpentieva, M. R., \& Kassymova, G. K. The negative impact of the internet on the educational process. International youth scientific conference "Heat and mass transfer in the thermal control system of technical and technological energy equipment”, 2019. https://doi.org/10.1063/1.5120671

[5] Novikov, A. M. On aspects and levels of developpment of professional culture of a specialist. (Новиков А. М. Об аспектах и уровнях развития профессиональной культуры специалиста) (In Russian). Retrieved from the website: http://www.anovikov.ru/artikle/urov.pdf

[6] Ponomarev, I. Р. Peculiarities of management training // Management in Russia and abroad. (Пономарев И. П. Особенность обучения менеджменту // Менеджмент в России и за рубежом). 2002. № 5. -P. 130-139 (In Russian)

[7] Zboryovskii, G. E. Information Resource for Information Society // Sociological Research (Зборовский Г. Е. Образование как ресурс информационного общества//Социологические исследования). 2005. №7. -P.107 (In Russian) 